\title{
Effect of Trichoderma and fungicide on seedling establishment and yield performance of dry direct seeded boro rice
}

\author{
M. M. Hassan ${ }^{1}$, S. Hossain ${ }^{1}$, M. M. Rahman ${ }^{2}$ and S. Mahmud ${ }^{3}$ \\ ${ }^{1}$ Agricultural Extension Officer, DAE, ${ }^{2}$ Department of Agronomy, Bangladesh Agricultural University, Mymensingh- \\ 2202 and ${ }^{3}$ Agronomy Division, Bangladesh Agricultural Research Institution, Bangladesh \\ E-mail: saikatbau1939@gmail.com
}

\begin{abstract}
Poor seedling establishment and seedling mortality is the major barrier to optimum stand establishment in dry direct seeded boro rice. Experiments were carried out at the Agronomy Field Laboratory, Bangladesh Agricultural University (BAU), Mymensingh, Bangladesh during January to June 2013 to study the effect of Trichoderma and fungicide application on seedling establishment and yield performance of dry direct seeded Boro rice. The experiment comprised ten treatment combinations of Trichoderma and fungicides viz. seed treatment with Trichoderma $\left(\mathrm{M}_{1}\right)$, seed treatment with Trichoderma+spraying of Thiovit $\left(\mathrm{M}_{2}\right)$, seed treatment with Trichoderma + spraying of Propiconazole $\left(\mathrm{M}_{3}\right)$, seed treatment with Trichoderma + spraying of Thiovit and Propiconazole $\left(\mathrm{M}_{4}\right)$, spraying of Thiovit $\left(M_{5}\right)$, spraying of Propiconazole $\left(M_{6}\right)$, seed treatment with Thiovit + spraying of Propiconazole $\left(M_{7}\right)$, seed treatment with Propiconazole + spraying of Thiovit $\left(M_{8}\right)$, spraying of mixture of Thiovit and Propiconazole $\left(\mathrm{M}_{9}\right)$, and control (no fungicide or Trichoderma ) $\left(\mathrm{M}_{10}\right)$. The experiments used Randomized Complete Block Design (RCBD) with three replications. Experiment revealed that seed treatment with Trichoderma harzianum followed by spraying of Thiovit gave the highest yield of rice. The study concludes that Trichoderma and then application of sulphur fungicide at 20 days after sowing could be practiced for ensuring high seedling establishment and yield of rice under dry direct seeded system in boro season.
\end{abstract}

Keywords: Trichoderma harzianum, Fungicide, Seedling, Boro rice

\section{Introduction}

Rice is the most important and extensively cultivated cereal crop in Bangladesh and it contributes to ninety five percent of the total food grain consumed. It is cultivated in 11.527 million hectare of land which is about $80 \%$ of the total cultivated land (14.41 million hectares) of Bangladesh. The total production of rice was 30.415 million metric tons in 2012-13. Rice is usually cultivated in three growing seasons (viz. Aus, Aman and Boro). The contribution of Boro, Aman and Aus rice production in 2011-12 were 53.81\%, $38.27 \%$ and $7.91 \%$, respectively (BBS, 2013). As Boro rice gives the highest yield among the three seasons, farmers are very much interested to grow Boro rice. In Bangladesh Boro rice is mainly cultivated in puddle transplanted system that requires huge amount of water. The crop can successfully be grown by direct seeding on dry un-puddled soil with less irrigation (Bouman et al., 2005) that would save 50-70\% of irrigation water (Peng et al., 2006). About $60 \%$ irrigation water compared with puddle transplanting system (Mandal et al., 2009 and Rahman et al., 2012) can be saved if Boro rice is cultivated in dry direct seeded system. It can also save diesel and electricity as well as save the environment by decreasing the emission of methane and carbon dioxide. Poor seedling establishment is a major constraint in adopting of dry direct seeded Boro rice cultivation system (Itabari et al., 1993). Optimum crop stand establishment is the prerequisite for successful crop production. Crops often fail to establish quickly and uniformly, leading to decreased yield because of low plant population. Seedling establishment of crops depends on the infestation of soil and seed borne fungi, lack of soil moisture, low temperature and low germination percentage of seed and so on. At low temperature, soil and seed borne fungi are to be more active to kill the seedlings of Boro rice. Seed treatment with Trichoderma and application of fungicide (sulphur or others) could be overcome the seedlings death.

BAU-biofungicide named Trichoderma harzianum is invented from naturally occurring fungus to protect crops from different diseases caused by different harmful fungi. Trichoderma protects seeds from huge number of soil borne as well as seed borne fungi that can attack the seeds before germination and after germination in the soil. It also controls pre-emergence and post-emergence death of seedlings. Seed treatment with Trichoderma significantly increases germination and protects seed and seedling from soil 
borne fungi as well as increase plant stand in the field (Hossain, 2011). So the establishment of seedling in the field is increased by the treatment of seed with Trichoderma and ultimately the crop yield is increased. The application of sulphur fungicide or other fungicides increased germination percentage, field emergence and percent survival. Thiovit increased the yield, depending on the rate and time of spraying, by $11-55 \%$ (Jarvan and Kuskla, 2005). The highest seed yield was found in the Vitavax- 200treated seeds (Jain, 2004). So application of fungicides can help crop establishment by increasing field emergence and percent survival.

The above discussion indicates seed treatment with Trichoderma harzianum and application of fungicides are the effective tools for rapid and uniform seedling emergence and increase the survival rate of crop plants as well as help to increase yield. However, these techniques have not yet been developed in Bangladesh. The present study sought to investigate the effect of Trichoderma and fungicide application on seedling establishment and yield performance of dry direct seeded Boro rice.

\section{Materials and Methods}

The experiment was conducted at the Agronomy Field Laboratory, Bangladesh Agricultural University (BAU), Mymensingh, Bangladesh during Boro season from January to June 2013. The experimental field is located at $24^{\circ} 25^{\prime} \mathrm{N}$ latitude and $90^{\circ} 50^{\prime} \mathrm{E}$ longitude having an altitude of $18 \mathrm{~m}$. The experimental site is a medium high land belonging to the Sonatala series of Old Brahmaputra Floodplain Agro-ecological Zone (AEZ-9). The soil was silt loam with $\mathrm{pH} 6.5$. Soil contained $1.78 \%$ organic matter, $0.14 \%$ total $\mathrm{N}, 1.98 \mu \mathrm{g}$ $\mathrm{g}^{-1}$ available $\mathrm{P}, 0.10 \mathrm{meq} 100 \mathrm{~g}^{-1}$ exchangeable $\mathrm{K}$ and $4.56 \mathrm{\mu g} \mathrm{g}^{-1}$ available $\mathrm{S}$. The crop experienced very low rainfall $(0-15 \mathrm{~mm})$ during January - March which coincided with the vegetative stage. The experiment comprised ten treatment combinations viz. seed treatment with Trichoderma $\left(M_{1}\right)$, seed treatment with Trichoderma+spraying of Thiovit $\left(\mathrm{M}_{2}\right)$, seed treatment with Trichoderma + spraying of Propiconazole $\left(\mathrm{M}_{3}\right)$, seed treatment with Trichoderma + spraying of Thiovit and Propiconazole $\left(M_{4}\right)$, spraying of Thiovit $\left(M_{5}\right)$, spraying of Propiconazole $\left(M_{6}\right)$, seed treatment with Thiovit + spraying of Propiconazole $\left(M_{7}\right)$, seed treatment with Propiconazole + spraying of Thiovit $\left(\mathrm{M}_{8}\right)$, spraying of mixture of Thiovit and Propiconazole $\left(\mathrm{M}_{9}\right)$, and control (no fungicide or Trichoderma ) $\left(\mathrm{M}_{10}\right)$. Treatment combinations were assigned to Randomized Complete Block Design (RCBD) with three replications. The plot size was $4.0 \mathrm{~m} \times 2.5 \mathrm{~m}$ maintained a plant spacing of $25 \mathrm{~cm} \times 15 \mathrm{~cm}$. BRRI dhan28 was was sown in furrows with $4-5$ seeds hill ${ }^{-1}$ on 16 January 2013 under dry direct seeded system. Trichoderma harzianum inoculums, a BAUbiofungicide was mixed at the rate of $4 \%$ of seed weight just before seed sowing (Hossain, 2011). The experimental plots were fertilized with well decomposed cow dung @ $5 \mathrm{t} \mathrm{ha}^{-1}$. The land was fertilized with urea, triple supper phosphate (TSP), muriate of potash (MoP), gypsum and zinc sulphate @ 120, 14, 58, 8 and $1 \mathrm{~kg} \mathrm{ha}^{-1}$ (BARC, 2005). Sulphur fungicide Thiovit (80\% Sulphur) and propiconazol fungicide (Potent) were applied in every plot at 20 DAS at the rate of $2.5 \mathrm{~kg} \mathrm{ha}^{-1}$ and 0.5 litre per hectare, respectively. Five grams of Thiovit was mixed with 1 litre of water and $1 \mathrm{ml}$ Potent was mixed with 1 litre of water. Weeding was done by hand with niri and by the application of herbicide. Panida (Pendimethalin) was applied at 2 DAS as pre-emergence herbicide at the rate of 2 litre ha ${ }^{-1}$. Only 2 irrigations were required for keeping 2-3 cm standing water in the crop field.. Irrigation water was measured by volumetric method (Misra and Ahmed, 1987). The crop was harvested on 31 May 2013 at maturity stage. At 10, 18 and 30 DAS emerged seedlings of central fourth and fifth lines $\left(2 \mathrm{~m}^{2}\right)$ of each plot were counted and converted into per square meter. Randomly ten seedlings were uprooted from $1 \mathrm{~m}$ inside of each plot at 30 DAS. Average shoot and root length of the seedlings were measured with a scale in centimeter $(\mathrm{cm})$. At panicle initiation $(\mathrm{PI})$ stage (77 DAS), randomly ten rice plants were cut with a sickle at soil level from about 1 meter inside of each experimental plot. Shoot length was measured with a scale in $\mathrm{cm}$ and the mean of ten shoots was shoot length $(\mathrm{cm})$ seedling $^{-1}$. At 30 DAS ten Shoots and roots were uprooted, cut, separated and dried at $70{ }^{\circ} \mathrm{C}$ for 72 hours in an oven. Then they were cooled at room temperature and weighed by an electric balance in gram (g) to calculate average shoot and root dry matter $(\mathrm{g})$ seedlings ${ }^{-1}$. Average plant height was calculated. Number of tillers $\mathrm{m}^{-2}$ was counted from the harvested crop. Number of panicles (effective tillers) $\mathrm{m}^{-2}$ was also calculated. Ten panicles were selected to calculate average panicle length. Number of filled grain or grain and sterile spikelets in each panicle was counted. Then grains panicle ${ }^{-1}$ and sterile spikelets panicle ${ }^{-1}$ was measured by calculating the mean 
value. One thousand clean dried grains were counted at $14 \%$ moisture .Grain yield and straw yield was also measured at $14 \%$ moisture content after sun drying, cleaning and weighing separately and finally converted into $\mathrm{t} \mathrm{ha}^{-1}$. Harvest index was calculated as percentage of grain yield to total above ground biomass. The data were compiled and tabulated in proper form and subjected to statistical analysis. Analysis of variance (ANOVA) was done with the help of computer package program MSTAT-C and mean comparisons of the treatments were evaluated by Duncan's Multiple Range Test (DMRT) (Gomez and Gomez, 1984).

\section{Results and Discussion}

Number of seedlings was significantly influenced by seed treatment with Trichoderma. However the highest numbers $86.66,113.00$ and $112.33 \mathrm{~m}^{-2}$ of seedling at 10,18 and 30 DAS was observed from seed treatment with Trichoderma respectively. The lowest number of seedling was found in no Trichoderma and fungicide application (Table 1). It is revealed that seed treatment with Trichoderma produced higher number of seedlings. This result is consistent with that of Hamed et al. (2011) and Rahman (2006). Shoot and root length was significantly influenced by seed treatment with Trichoderma. The highest shoot and root length $(20.19$ and $8.25 \mathrm{~cm}$ ) was recorded from seed treatment with Trichoderma and those found lowest $(16.10$ and $5.82 \mathrm{~cm}$ ) from no Trichoderma and fungicide application (Table 2). It clearly indicates that seed treatment with Trichoderma gained higher shoot and root length. Azarmi et al. (2011) and Nzanza et al. (2011) also found that $T$. harzianum treated plants improved shoot and root length. Shoot dry and root dry matter was significantly influenced by Trichoderma and sulphur fungicide application. The highest shoot dry matter $(22.59 \mathrm{~g})$ was found from seed treatment with Trichoderma and spraying of propiconazole fungicide at 20 DAS and at the same time the highest root dry matter $(9.95 \mathrm{~g})$ was found by seed treatment with Trichoderma (Table 2). The lowest shoot and root dry matter (18.54 and $6.98 \mathrm{~g})$ was observed in no Trichoderma or fungicide application (Table 2). It is revealed that seed treatment with Trichoderma and spraying of sulphur fungicide (propiconazole) produced higher shoot and root dry matter. The result of the present study supports to Azarmi et al. (2011) and Nzanza et al. (2011) that was the highest shoot and root dry matter with Trichoderma treatment over the control.

Seed treatment with Trichoderma and fungicide had no significant effect on plant height and panicle length. However, numerically the highest number of tillers $\left(426.00 \mathrm{~m}^{-2}\right)$ and highest number of panicle $\left(380.33 \mathrm{~m}^{-2}\right)$ was observed from seed treatment with Trichoderma and spraying of sulphur fungicide at 20 DAS (Table 3). The numerical highest number of grain $\left(98.00\right.$ panicle $\left.^{-1}\right)$ was obtained from seed treatment with Trichoderma and spraying of sulphur fungicide at 20 DAS. The lowest number of grain (75.66 panicle ${ }^{-1}$ ) was obtained from no fungicide or Trichoderma application (Table 4). There was no significant difference in 1000-grain weight and number of sterile spikelets due to the effect of Trichoderma and fungicide application (Table 4).

Grain yield was significantly influenced by seed treatment with Trichoderma and spraying of sulphur fungicide at 20 DAS. The highest grain yield $\left(6.28\right.$ tha $\left.^{-1}\right)$ was obtained from seed treatment with Trichoderma and spraying of sulphur fungicide at 20 DAS and lowest grain yield $\left(3.41\right.$ tha $\left.^{-1}\right)$ was obtained from no fungicide or Trichoderma application (Table 4). This indicates that seed treatment with Trichoderma and spraying of sulphur fungicide at 20 DAS produced higher grain yield. Our results were in accordance with Islam (2009) and Shultana et al. (2009) who found similar significant efficacy of BAU biofertilizer.

Straw yield was significantly influenced by seed treatment with Trichoderma. The highest straw yield (7.54 tha $^{-1}$ ) was gained from seed treatment with Trichoderma and lowest straw yield $\left(4.12\right.$ tha $\left.^{-1}\right)$ was obtained from no fungicide or Trichoderma application (Table 4). It clearly indicates that seed treatment with Trichodema produced higher straw yield. This result was consistent with findings of Hossain et al. (2009). Seed treatment with Trichoderma and fungicide had no significant effect on harvest index (Table 4). 
Table 1. Effect of Trichoderma and fungicide on number of seedlings of dry direct seeded Boro rice at 10,18 and 30 days after sowing

\begin{tabular}{cccc}
\hline Treatment & $\begin{array}{c}\text { No. of seedlings } \\
\mathrm{m}^{-2} \text { at 10 DAS }\end{array}$ & $\begin{array}{c}\text { No. of seedlings } \\
\mathrm{m}^{2} \text { at 18 DAS }\end{array}$ & $\begin{array}{c}\text { No. of seedlings } \\
\mathrm{m}^{-2} \text { at 30 DAS }\end{array}$ \\
\hline $\mathrm{M}_{1}$ & $86.66 \mathrm{a}$ & $113.00 \mathrm{a}$ & $111.66 \mathrm{a}$ \\
$\mathrm{M}_{2}$ & $85.33 \mathrm{a}$ & $112.66 \mathrm{a}$ & $112.33 \mathrm{a}$ \\
$\mathrm{M}_{3}$ & $83.33 \mathrm{a}$ & $111.33 \mathrm{a}$ & $109.66 \mathrm{a}$ \\
$\mathrm{M}_{4}$ & $85.00 \mathrm{a}$ & $109.66 \mathrm{a}$ & $107.66 \mathrm{a}$ \\
$\mathrm{M}_{5}$ & $51.33 \mathrm{~b}$ & $79.33 \mathrm{~b}$ & $73.33 \mathrm{~b}$ \\
$\mathrm{M}_{6}$ & $52.00 \mathrm{~b}$ & $78.00 \mathrm{~b}$ & $69.66 \mathrm{~b}$ \\
$\mathrm{M}_{7}$ & $83.00 \mathrm{a}$ & $107.66 \mathrm{a}$ & $106.00 \mathrm{a}$ \\
$\mathrm{M}_{8}$ & $77.00 \mathrm{a}$ & $106.33 \mathrm{a}$ & $105.00 \mathrm{a}$ \\
$\mathrm{M}_{9}$ & $45.00 \mathrm{~b}$ & $71.66 \mathrm{~b}$ & $65.00 \mathrm{~b}$ \\
$\mathrm{M}_{10}$ & $48.66 \mathrm{~b}$ & $74.00 \mathrm{~b}$ & $65.00 \mathrm{~b}$ \\
\hline $\mathrm{Lsd}$ & 10.33 & 10.52 & 9.612 \\
$\mathrm{~S}$ & 3.476 & 3.540 & 3.235 \\
\hline $\mathrm{CV}(\%)$ & $8.63^{* *}$ & $6.36^{* *}$ & $6.06^{* *}$ \\
\hline
\end{tabular}

Note: ${ }^{*}$ and ${ }^{* *}$ indicate at $1 \%$ and $5 \%$ level of significance

DAS - Days after sowing

Table 2. Effect of Trichoderma and fungicide on shoot and root dry matter of direct seeded Boro rice

\begin{tabular}{ccccc}
\hline Treatment & $\begin{array}{c}\text { Shoot length at 30 } \\
\text { DAS }(\mathrm{cm})\end{array}$ & $\begin{array}{c}\text { Root length at 30 } \\
\text { DAS }(\mathrm{cm})\end{array}$ & $\begin{array}{c}\text { Shoot dry matter } \\
\text { at 30 DAS }(\mathrm{g})\end{array}$ & $\begin{array}{c}\text { Root dry matter at 30 } \\
\text { DAS }(\mathrm{g})\end{array}$ \\
\hline $\mathrm{M}_{1}$ & $20.19 \mathrm{a}$ & $8.25 \mathrm{a}$ & $21.98 \mathrm{ab}$ & $9.95 \mathrm{a}$ \\
$\mathrm{M}_{2}$ & $19.12 \mathrm{abc}$ & $7.15 \mathrm{abc}$ & $22.42 \mathrm{a}$ & $8.75 \mathrm{ab}$ \\
$\mathrm{M}_{3}$ & $19.73 \mathrm{ab}$ & $6.32 \mathrm{bcd}$ & $22.59 \mathrm{a}$ & $8.30 \mathrm{ab}$ \\
$\mathrm{M}_{4}$ & $18.38 \mathrm{abcd}$ & $7.32 \mathrm{ab}$ & $21.31 \mathrm{abc}$ & $7.82 \mathrm{~b}$ \\
$\mathrm{M}_{5}$ & $17.71 \mathrm{bcd}$ & $6.26 \mathrm{bcd}$ & $18.94 \mathrm{c}$ & $7.00 \mathrm{~b}$ \\
$\mathrm{M}_{6}$ & $17.60 \mathrm{bcd}$ & $6.11 \mathrm{bcd}$ & $18.70 \mathrm{c}$ & $7.54 \mathrm{~b}$ \\
$\mathrm{M}_{7}$ & $18.73 \mathrm{abc}$ & $6.83 \mathrm{bcd}$ & $20.95 \mathrm{abc}$ & $8.13 \mathrm{~b}$ \\
$\mathrm{M}_{8}$ & $18.41 \mathrm{abcd}$ & $6.73 \mathrm{bcd}$ & $19.77 \mathrm{abc}$ & $8.75 \mathrm{ab}$ \\
$\mathrm{M}_{9}$ & $16.78 \mathrm{~cd}$ & $6.03 \mathrm{~cd}$ & $19.24 \mathrm{bc}$ & $7.02 \mathrm{~b}$ \\
$\mathrm{M}_{10}$ & $16.10 \mathrm{~d}$ & $5.82 \mathrm{~d}$ & $18.54 \mathrm{c}$ & $6.98 \mathrm{~b}$ \\
\hline Lsd & 2.117 & 1.11 & 2.544 & 1.63 \\
$\mathrm{~S}$ & 0.7125 & 0.3737 & 0.856 & 0.5486 \\
\hline $\mathrm{CV}(\%)$ & $6.75^{*}$ & $9.68^{* *}$ & $7.25^{*}$ & $11.84^{*}$ \\
\hline
\end{tabular}

Note: * and ** indicate at $1 \%$ and $5 \%$ level of significance DAS - Days after sowing 
Table 3. Effect of Trichoderma and fungicide on different growth status of dry direct seeded Boro rice

\begin{tabular}{ccccc}
\hline Treatment & $\begin{array}{c}\text { Plant } \\
\text { height }(\mathrm{cm})\end{array}$ & $\begin{array}{c}\text { No. of } \\
\text { tillers } \mathrm{m}^{-2}\end{array}$ & $\begin{array}{c}\text { No. of } \\
\text { panicles } \mathrm{m}^{-2}\end{array}$ & $\begin{array}{c}\text { Panicle } \\
\text { length }(\mathrm{cm})\end{array}$ \\
\hline $\mathrm{M}_{1}$ & 98.06 & $411.33 \mathrm{a}$ & $364.00 \mathrm{a}$ & 22.62 \\
$\mathrm{M}_{2}$ & 100.00 & $426.00 \mathrm{a}$ & $380.33 \mathrm{a}$ & 22.73 \\
$\mathrm{M}_{3}$ & 97.93 & $320.66 \mathrm{bcd}$ & $300.33 \mathrm{~b}$ & 23.83 \\
$\mathrm{M}_{4}$ & 98.73 & $319.33 \mathrm{bcd}$ & $276.66 \mathrm{bc}$ & 22.17 \\
$\mathrm{M}_{5}$ & 98.20 & $340.33 \mathrm{~b}$ & $267.00 \mathrm{bcd}$ & 24.16 \\
$\mathrm{M}_{6}$ & 96.80 & $337.66 \mathrm{bc}$ & $288.33 \mathrm{~b}$ & 22.59 \\
$\mathrm{M}_{7}$ & 96.66 & $324.00 \mathrm{bc}$ & $270.00 \mathrm{bcd}$ & 23.14 \\
$\mathrm{M}_{8}$ & 99.00 & $326.00 \mathrm{bc}$ & $276.33 \mathrm{bc}$ & 23.52 \\
$\mathrm{M}_{9}$ & 97.13 & $287.33 \mathrm{~d}$ & $251.00 \mathrm{~cd}$ & 22.50 \\
$\mathrm{M}_{10}$ & 97.00 & $302.66 \mathrm{~cd}$ & $237.66 \mathrm{~d}$ & 22.45 \\
\hline Lsd & 4.104 & 31.55 & 30.97 & 1.836 \\
$\mathrm{~S}$ & 1.381 & 10.62 & 10.42 & 0.618 \\
$\mathrm{CV}(\%)$ & $2.44^{\text {NS }}$ & $5.42^{* *}$ & $6.20^{* *}$ & $4.66^{\text {NS }}$ \\
\hline
\end{tabular}

Note: * and ${ }^{* *}$ indicate at $1 \%$ and $5 \%$ NS - Not significant

Table 4. Effect of Trichoderma and fungicide on yield contributing characters and yield of dry direct seeded Boro rice

\begin{tabular}{ccccccc}
\hline Treatment & $\begin{array}{c}\text { No. of } \\
\text { grain } \\
\text { pancle }\end{array}$ & $\begin{array}{c}\text { No. of } \\
\text { sterile } \\
\text { spikelets } \\
\text { pancle }^{-1}\end{array}$ & $\begin{array}{c}1000 \\
\text { grain } \\
\text { wt(g) }\end{array}$ & $\begin{array}{c}\text { Grain } \\
\text { yield } \\
\left(\mathrm{t} \mathrm{ha}^{-1}\right)\end{array}$ & $\begin{array}{c}\text { Straw } \\
\text { yield } \\
\left(\mathrm{t} \mathrm{ha}{ }^{-1}\right)\end{array}$ & $\begin{array}{c}\text { Harvest } \\
\text { index } \\
(\%)\end{array}$ \\
\hline $\mathrm{M}_{1}$ & $92.66 \mathrm{c}$ & 15.66 & 22.09 & $6.08 \mathrm{ab}$ & $7.54 \mathrm{a}$ & 44.64 \\
$\mathrm{M}_{2}$ & $98.00 \mathrm{a}$ & 18.00 & 21.72 & $6.28 \mathrm{a}$ & $7.45 \mathrm{a}$ & 45.72 \\
$\mathrm{M}_{3}$ & $93.00 \mathrm{c}$ & 17.00 & 21.68 & $5.65 \mathrm{bc}$ & $6.75 \mathrm{~b}$ & 45.55 \\
$\mathrm{M}_{4}$ & $90.00 \mathrm{~d}$ & 18.66 & 22.31 & $5.29 \mathrm{c}$ & $6.38 \mathrm{~b}$ & 45.32 \\
$\mathrm{M}_{5}$ & $78.66 \mathrm{~h}$ & 16.00 & 22.04 & $4.42 \mathrm{~d}$ & $5.47 \mathrm{c}$ & 44.68 \\
$\mathrm{M}_{6}$ & $87.33 \mathrm{f}$ & 19.00 & 22.13 & $4.69 \mathrm{~d}$ & $5.53 \mathrm{c}$ & 45.83 \\
$\mathrm{M}_{7}$ & $88.66 \mathrm{e}$ & 18.33 & 22.10 & $5.36 \mathrm{c}$ & $6.62 \mathrm{~b}$ & 44.80 \\
$\mathrm{M}_{8}$ & $96.00 \mathrm{~b}$ & 15.66 & 22.02 & $5.30 \mathrm{c}$ & $6.33 \mathrm{~b}$ & 45.54 \\
$\mathrm{M}_{9}$ & $83.33 \mathrm{~g}$ & 16.00 & 21.89 & $4.63 \mathrm{~d}$ & $5.68 \mathrm{c}$ & 44.93 \\
$\mathrm{M}_{10}$ & $75.66 \mathrm{i}$ & 16.00 & 21.74 & $3.41 \mathrm{e}$ & $4.12 \mathrm{~d}$ & 45.28 \\
\hline $\mathrm{Lsd}$ & 0.488 & 2.91 & 0.736 & 0.488 & 0.515 & 1.365 \\
$\mathrm{~S}$ & 0.164 & 0.980 & 0.248 & 0.164 & 0.173 & 0.459 \\
$\mathrm{CV}(\%)$ & $8.23^{*}$ & $9.96^{\mathrm{NS}}$ & $1.95^{\mathrm{NS}}$ & $5.57^{* *}$ & $4.85^{* *}$ & $1.76^{\mathrm{NS}}$ \\
\hline
\end{tabular}

Note: * and ${ }^{* *}$ indicate at $1 \%$ and $5 \%$ NS - Not significant 


\section{Conclusion}

Trichoderma along with the sulphur fungicide treatments can improve the seedling establishment and increase the yield of dry direct seeded Boro rice. The optimum number of seedlings and proper growth of seedlings could be achieved with the application of sulphur fungicide and Trichoderma treatments in dry direct seeded Boro rice.

\section{References}

Azarmi, R., Hajieghrari, B. and Giglou, A. 2011. Effect of Trichoderma isolates on tomato seedling growth response and nutrient uptake. African J. Biotech. 10(31): 5850-5855.

BARC(Bangladesh Agricultural Research Council). 2005. Fertilizer Recommendation Guide. Bangladesh Agricultural Research Council, Farmgate, New Airport Road, Dhaka. pp. 168-170.

BBS (Bangladesh Bureau of Statistics). 2013. Statistical Yearbook of Bangladesh. Bangladesh Bur. Stat., Stat. Div., Minis. Plann. Govt. People"s Repub. Bangladesh, Dhaka .pp. 123-127.

Bouman B.A.M., Peng, S., Castaneda, A.R. and Visperas. R.M. 2005. Yield and water use of irrigated tropical aerobic rice systems. Agric. Water Manage. 74: 87-105.

Gomez, K.A., and Gomez. A.A. 1984. Statistical Procedures for Agricultural Research. . A Wiley Int. Sci. Pub. John Wiley and Sons, New York, Brisbane, Singapore. pp. 139-240.

Hamed, K., Jartoodeh, S.V., Aruee, H. and Mazhabi, M. 2011. Would Trichoderma Affect Seed Germination and Seedling Quality of Two Muskmelon Cultivars, Khatooni and Qasri and Increase Their Transplanting Success. J. Biol. Environ. Sci. 5(15): 169-175.

Hossain, I. 2011. BAU-Biofungicide: Unique Eco-friendly Means and New Dimension of Plant Disease Control in Bangladesh. Department of Plant Pathology, Bangladesh Agricultural University, Mymensingh. pp. 8-10.

Hossain, S. 2009. Efficacy of BAU-Biofungicide and Fungicides in controlling leaf spot of wheat. An M. S. Thesis submitted to the Dept. of Plant Pathology, Bangladesh Agricultural University, Mymensingh.

Islam, S. 2009. Comparative efficacy of BAU-Biofungicide and Tilt in controlling diseases of rice. An M. S. Thesis submitted to the Dept. of Plant Pathology, Bangladesh Agricultural University, Mymensingh.

Itabari, J.K., Gregory, P.J. and Jones, R.K. 1993. Effects of temperature, soil \& water status and depth of planting on germination and emergence of maize adapted to semi-arid eastern Kenya. Exp. Agric. 29: 351-364.

Jain, A.K. 2004. Application of fungicides and antagonist for the management of head smut of kodo millet. Res. J. 38(2): 101-103.

Jarvan, M. and Kuskla, M. 2005. Effect of leaf-applied sulphur on yield structure elements and yield of winter wheat (Triticum aestivum). Transactions of the Estonian Agricultural University, Agron. 220: 63-65.

Mandal, S.N., Regmi, A.P., Ladha, J.K. and Tuong, T.P.2009. Crop establishment, tillage and watermanagement effects on crop and water productivity in rice-wheat rotation in Nepal. In Ladha, Yadvinder-Singh, J. K.and Erestein, O. Integrated Crop and Resource Management in the rice-wheat system of southAsia. Los Banos, Philippines: International Rice Research Institute pp. 133-150.

Misra, R.D. and Ahmed, M. 1987. Manual on Irrigation Agronomy. Oxford \& IBH Publishing Co. Pvt. Ltd, New Delhi, India. pp. 225226.

Nzanza, B., Marais, D. and Soundy, P. 2011. Tomato (Solanum lycopersicum L.) seedling growth and development as influenced by Trichoderma harzianum and arbuscular mycorrhizal fungi. African J. Microbiol. Res. 5(4): 425-431.

Peng, S.B., Bouman, R.M., Visperas, A., Castane, L., Nie and Hong-Kyu Park. 2006. Comparison between aerobic flooded rice in the tropics: Agronomic performance in an eight-season experiment. Field Crops Res. 96: 252-259.

Rahman, M.M. 2006. Biological control of seedling diseases of papaya, watermelon and melon. An M. S. thesis, submitted to the Department of Plant Pathology, Bangladesh Agricultural University, Mymensingh.

Rahman, M.M., Uddin, M.A. and Masood, M.M. 2012. Irrigation water saving, yield performance and cost effectiveness of different rice cultivation systems in Boro season. Banglasdesh Agron. J. 15(1): 99-106.

Shultana, R., Hossain, I., Ahmed, S. and Mamun, M.A.A. 2009. Efficacy of BAU-Biofungicide in controlling leaf spot of wheat (Triticum aestivum). Eco-friendly Agril. J. 2(2): 392-395. 